\title{
Indium-mediated Allylation of $\alpha$-Imino Esters in Aqueous Media
}

\author{
Xiane Piao, Jae-Kyung Jung, ${ }^{*}$ and Han-Young Kang \\ Department of Chemistry and Institute of Basic Sciences, Chungbuk National University, Cheongiu, Chungbuk 361-763, Korea \\ "E-mail: hykang(a,chungbuk.ac.kr \\ "College of Pharma'y, Chungbuk National University, Cheongin, Chungbuk 361-763, Konea \\ Received September 19, 2006
}

Key Words : Indium. Allylation, Allenylation, Aqueous media, $\alpha$-lmino ester

Indium-mediated allylation of carbonyl groups has attracted much attention due to the efficiency of achieving transformations in aqueous media. Since indium has gained great fame in chemical community for conducting allylation of $\mathrm{C}=\mathrm{O}$ bonds, numerous examples have been reported to recent years.' $\Lambda$ ddition of the allylindium reagent to imines, however, has not enjoyed popularity even though allylation of $\mathrm{C}=\mathrm{N}$ bond could be a natural extension of the allylation of carbonyl groups. Relative scarcity of reports on the addition of organometallic reagents to $\mathrm{C}=\mathrm{N}$ bonds, in general, should be ascribed to the poor electrophilicity of the imines compared to the corresponding carbonyl groups. Therefore, it is often required to have organometallic reagents with higher reactivity or attaching the activating group to facilitate the addition. This is also the case for the allylation of $\mathrm{C}=\mathrm{N}$ bond mediated by indium, especially in aqueous media due to the low electrophilicity of imines, ease of being hydrolyzed, and tendency to produce homocoupling products. ' Indiummediated allylations of $\mathrm{C}=\mathrm{N}$ bonds in aprotic organic solvents, including $\mathrm{THF}^{3}$ and $\mathrm{DMF}^{4}$ has also been reported. Indium-mediated allylation of unactivated aldimines has been conducted in alcoholic solvent as an example of using protic solvents. ${ }^{5}$ In this case allylation to $\mathrm{C}=\mathrm{N}$ bonds in water was not successful and only produced the corresponding homoallylic alcohol via presumed indium salt-catalyzed hydrolysis of imines. Asymmetric allylation of aldimines in alcoholic solvents to synthesize optically active homoallylic amines has also appeared."

Chan has first achieved the indium-mediated allylation of imines in aqueous media by employing sulfonimines instead of simple inines. The success of addition was ascribed to the enhanced electrophilicity due to the electron-withdrawing ability of the sulfonyl group. ${ }^{7}$ Indium-mediated allylation of tosyl and aryl hydrazones and nitrones has been performed in DMP-I I $\mathrm{I}_{2} \mathrm{O}$ system. ${ }^{8}$ It is also noteworthy to mention that propargylation of imines and imine oxides in $\mathrm{TI}\left[\mathrm{F}-\mathrm{I}_{2} \mathrm{O}\right.$ has also been reported. ${ }^{9}$

Imines derived from glyoxylic acid derivatives have also been used as substrates for indium-mediated allylations. Glyoxylate oxime $1\left(\mathrm{R}^{\prime}=\mathrm{H}\right)$ or oxime ethers $1\left(\mathrm{R}^{\prime}=\right.$ alkyl) has been investigated as substrates for indium-mediated allylations of $\mathrm{C}=\mathrm{N}$ bonds. Since $\mathrm{C}=\mathrm{N}$ bonds in oxime glyoxylates (as well as $\alpha$-imino esters 2 ) are activated due to existence of COOR, facile addition of allylindium is anticipated. In fact, addition of allylzinc reagents, which exhibit similar behavior to allylindium reagents, to $\mathrm{C}=\mathrm{N}$ bonds was reported by Ilannesian. ${ }^{\text {(t) }}$

There have been a few reports on the indium-mediated allylation of glyoxylic oxime ethers in aqueous media. Asymmetric synthesis of $\alpha$-amino acids by allylation of glyoxylic oxime ethers having Oppolzer"s camphorsultam as a chiral auxiliary $\left(2^{\prime}\right)$ has been conducted." Two other reports on allylation of glyoxylic oxime ethers in aqueous media have appeared. ${ }^{12}$ Similar and still interesting allylation with palladium-indium iodide has been investigated with respect to regioselectivity and role of water added in enhancing diastereoselectivity. ${ }^{\text {is }}$

Despite these few reports, the allylation reactions mediated by indium on PMP (p-methoxyphenyl)-protected $\alpha$-imino esters 3 have not been investigated. We have been interested in indium-mediated allylation of $\alpha$-imino esters 3 especially in aqueous media. Here we wish to report our efforts on Barbier-type allylation of $\alpha$-imino esters 3 mediated by indium in aqueous media.

We chose a PMP-protected $\alpha$-imino ester 3a $(\mathrm{R}=\mathrm{Et})$ as a substrate for indium-mediated allylation in organic and aqueous media. Results of the indium or zinc-mediated allylation of $\alpha$-imino ethyl ester 3a were summarized in Table $\mathrm{l}$.<smiles>[R]ON=CC(=O)O[R]</smiles>

1<smiles>[R]N=CC([R])=O</smiles>

2<smiles>[R]N=CC([X])=O</smiles>

$2^{\prime}$

$\mathrm{X}^{*}=$ Oppolzer's camphorsultam<smiles>[R]OC(=O)/C=N/c1ccc(OC)cc1</smiles>

3a $\mathrm{R}=\mathrm{Et}$ 
Table 1. Indium or zinc-mediated allylation of PMP ( $p$-methoxyphenyl)-protected $x$-imino ethyl ester ${ }^{\prime i}$

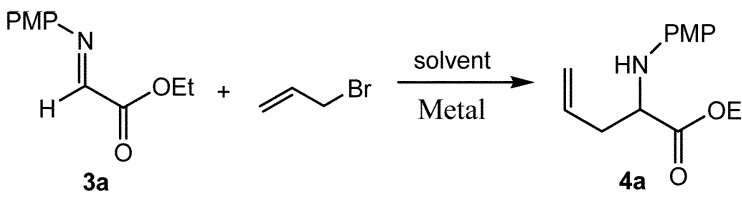

\begin{tabular}{|c|c|c|c|c|}
\hline Entry & Solvent ${ }^{h}$ & Metal & $\begin{array}{l}\text { Time } \\
\text { (l) }\end{array}$ & $\begin{array}{l}\text { lsolated } \\
\text { Yield (\%) }\end{array}$ \\
\hline 1 & THF & In & 3 & 81 \\
\hline 2 & THF: $\mathrm{H}_{2} \mathrm{O}(1: 1)$ & In & 18 & 59 \\
\hline 3 & THF: $\mathrm{NH}_{4} \mathrm{Cl} / \mathrm{H}_{2} \mathrm{O}(\mathrm{I}: 1)$ & In & 5 & 88 \\
\hline 4 & DMF & In & 3 & 82 \\
\hline 5 & DMF: $\mathrm{H}_{2} \mathrm{O}(1: 1)$ & In & 5 & 68 \\
\hline 6 & DMF: $\mathrm{NH}_{+} \mathrm{Cl}_{2} \mathrm{O}(1: 1)$ & In & 5 & 67 \\
\hline 7 & $\mathrm{ElOH}$ & In & 3 & 46 \\
\hline 8 & $\mathrm{H}_{2} \mathrm{O}$ & $\ln$ or $\mathrm{Zn}$ & 24 & NR \\
\hline 9 & $\mathrm{E} 1 \mathrm{OH}: \mathrm{NH}_{4} \mathrm{Cl} / \mathrm{H}_{2} \mathrm{O}(\mathrm{I}: 1)$ & $\ln$ & 5 & 36 \\
\hline 10 & THF & $\mathrm{Zn}$ & 3 & 83 \\
\hline 11 & THF: $\mathrm{H}_{2} \mathrm{O}(1: 1)$ & $\mathrm{Zn}$ & 5 & 62 \\
\hline 12 & THF: $\mathrm{NH}_{4} \mathrm{Cl} / \mathrm{H}_{2} \mathrm{O}(\mathrm{I}: 1)$ & $\mathrm{Zn}$ & 4 & 88 \\
\hline 13 & DMF & $\mathrm{Zn}$ & 3 & 80 \\
\hline 14 & DMF: $\mathrm{H}_{2} \mathrm{O}(1: 1)$ & $\mathrm{Zn}$ & 5 & 66 \\
\hline 15 & DMF: $\mathrm{NH}_{+} \mathrm{Cl}_{2} \mathrm{H}_{2} \mathrm{O}(1: 1)$ & $\mathrm{Zn}$ & 3 & 69 \\
\hline 16 & $\mathrm{ElOH}$ & $\mathrm{Zn}$ & 3 & 45 \\
\hline 17 & $\mathrm{E} 1 \mathrm{OH}: \mathrm{NH}_{4} \mathrm{Cl}_{2} \mathrm{H}_{2} \mathrm{O}(\mathrm{I}: 1)$ & $\mathrm{Zn}$ & 5 & 37 \\
\hline
\end{tabular}

"The following molar ratios were used: $\mathbf{3 a}$ ( 1.0 equiv), allyl bromide (2.0

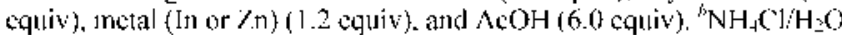
means that saturated aqueous ammonium chloride wask used.

As expected the allylation reactions underwent efficiently in organic solvents such as THF and DMF with both metals (entries 1, 4, 10, and 13) at room temperature. However, allylation in ethanol only proceeded in low yield either with In or Zn (entries 7 and 16). More imporlantly, we have tested the reaction in aqueous media. Addition of water to organic solvents resulted in reduction of yields (entries 2, 5, 11, and 14). Fortunately, employing saturated aqueous ammonium chloride restored the yields up to the level of using organic solvents such as THF and DMF only. The equal ratio of organic solvents and aqueous saturated $\mathrm{NH}_{4} \mathrm{Cl}$ solution $(1: 1$ $(v / v)$ offered optimum yields. Among organic solvents tested, THF provided the best yield of the allylations when aqueous saturated $\mathrm{NH}_{4} \mathrm{Cl}$ solution was added (entry 3 ). Addition of lesser amount of water or further addition of water led to lowering of yields. Use of water only as a solvent prohibited the reaction (entry 8) to provide the allylated product.

Since allylation to the PMP-protected $\alpha$-imino ester 3a was most efficiently achieved with indium in THF : $\mathrm{NH}_{4} \mathrm{Cl} /$ $\mathrm{H}_{2} \mathrm{O}(1: 1)$. Several allylic bromides and propargyl bromide were tested for addition under this condition (Table 2). With 3-methyl-2-butenyl bromide allylation took place at $\gamma$ position. No a-allylation was observed (entries 2). Even with propargyl bromide allenylation only occurred (entry 4). All reactions in Table 2 was achieved in good yield and
Table 2. Indium-mediated allylation of PMP (p-methoxyphenyl)protected $\alpha$-imino ethyl ester with various allyl bromides

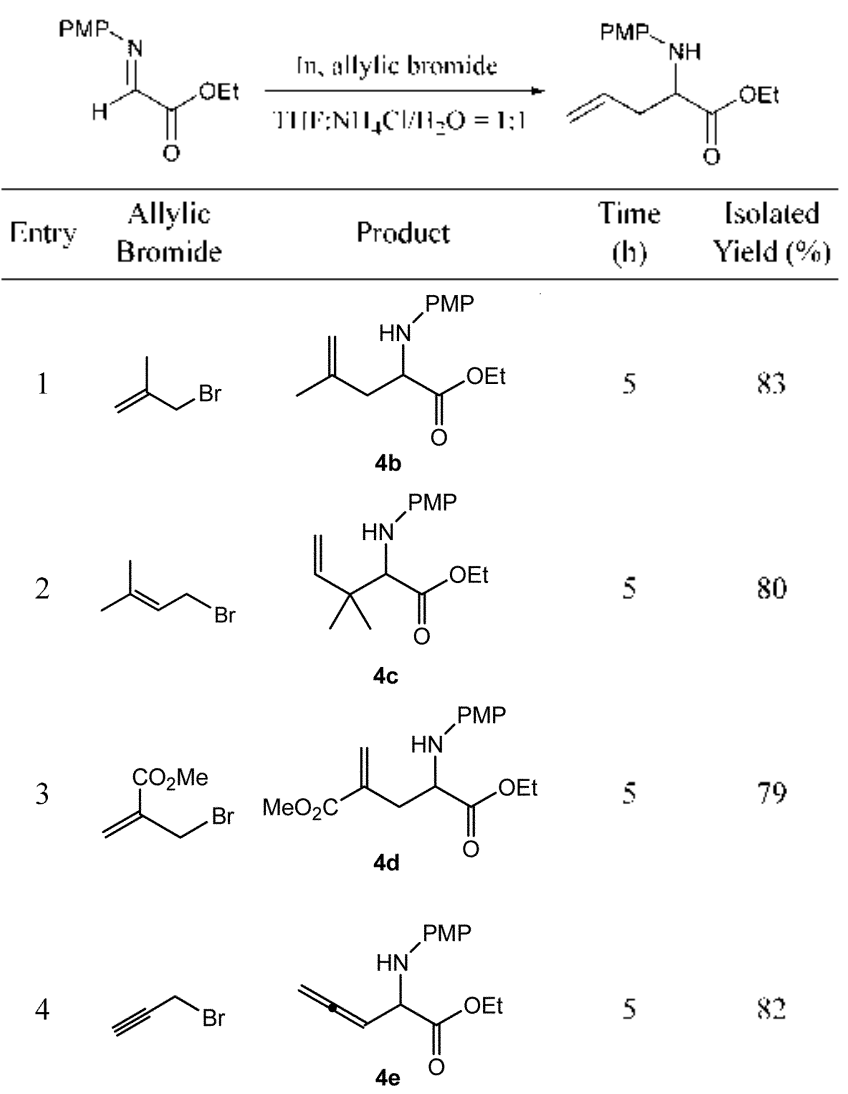

"The following molar ratios werc uscd: 3 a ( 1.0 cquiv), allyl bromide (2.0 equiv), metal (In) ( 1.2 equiv), and AcOIl (6.0 equiv). TI IF and saluraled aqueous ammonium chloride was used as a solvent system.

completed in less than $3 \mathrm{~h}$.

The allylation was further simplified by starting with $\alpha$ ketoesters. Instead of using $\alpha$-imino ester 3a, $\alpha$-ketoester 5 was directly used a starting substrate without preparing PMP-protected $\alpha$-imino ester $\mathbf{3 a}$ as shown in the following equation.<smiles>C=CCC(NN(C)CCCCCC(=O)O)C(=O)OCC</smiles>

We have tested the one-pot reaction in THF (Table 3 ). Thus, $\alpha$-ketoester 5 and $p$-methoxyaniline $\mathbf{6}$ was dissolved and stirred for $15 \mathrm{~min}$ before allyl bromide and indium were added (Method $\mathrm{A}$ ). The resulting mixture was stirred until the reaction was completed. Three hours were enough to 
provide the allylated product 4a in good yicld in THF (entry 1). Switching to an aqueous solvent system (i.e., THF : $\mathrm{NH}_{4} \mathrm{Cl} / \mathrm{H}_{2} \mathrm{O}(1: 1)$ ) resulted in allylation also in good yield ( $85 \%$ ) (entry 2 ). Furthermore, it was also possible to perform the reaction by mixing all of the reagents $(5,6$, and allyl bromide as well as indium in the presence of acetic acid) in solvents at the same time (Method B). In THF this one-pot reaction provided the product in good yield (87\%) (entry 3). This one-pot allylation was, however, not efficient in THF : $\mathrm{NH}_{4} \mathrm{Cl}_{/} \mathrm{H}_{2} \mathrm{O}(1 ; 1)$ and only to give in $45 \%$ yield (entry 4). Onc-pot allylations were similarly achicved in good yields with other allylic bromides (Table 3, entries 57).

Fimploying the PMP (p-methoxybenzyl) group as the protecting group of imine functionality provided a unique opportunity to proceed the allylation in good yicld. Thus, reactions of $N$-benzylidenebenzylamine (7a) with the allylindium reagent generated by addition of allyl bromide and indium undergo efficiently to give 8a when anhydrous THF is used as a solvent. The reaction in water, however, only gave the corresponding homoallyl alcohol 9 (not 8a) in good yield presumably due to the allylation of the aldehyde derived from the hydrolysis of the imine $7 \mathbf{a},{ }^{5}$ We tested the allylation of $7 \mathrm{a}$ in $\mathrm{THF}: \mathrm{NH}_{4} \mathrm{Cl}_{2} / \mathrm{H}_{2} \mathrm{O}(1: 1)$ (the same condition as we selected for the efticient allylation of the PMP (p-methoxyphenyl) protected $\alpha$-imino ester 3a, see Table 1 and 2) and confirmed that the homoallylic alcohol 9 was formed in good yicld $(90 \%)$.

However, the PMP-protected aldimine 7 b was reacted with allyl bromide in the presenece of indium to provide the

Table 3. One-pot allylation starting with ethyl glyoxylate 5<smiles>CCOC(=O)C(=O)NC(CC=CCBr)C(=O)OCC</smiles>

\begin{tabular}{ccccc}
\hline Entry & $\begin{array}{c}\text { Allylic } \\
\text { Bromide }\end{array}$ \\
\hline 1 & Methot" & Solvent & \multicolumn{2}{c}{$\begin{array}{c}\text { Time Isolated } \\
\text { (h) }\end{array}$} \\
Yield (\%) \\
\hline
\end{tabular}

"Method $\Lambda: \alpha$-Ketoester 5 and $p$-methoxyaniline 6 wels dissolved and stirred for $15 \mathrm{~min}$ belore allyl bromide and indium were added. Method B: $x$-Ketoester 5 , $p$-methoxyaniline 6 , and allyl bromide was dissolved at the same line. corresponding allylated product $\mathbf{8 b}$ in good yicld both in THF and the aqueous system (THF : $\mathrm{NH}_{4} \mathrm{Cl}-\mathrm{H}_{2} \mathrm{O}(1: 1)$ ). This result has confirmed that the PMP group ean act to stabilize the aldimines by withdrawing electrons from the nitrogen atom and exert a favorable effect to facilitate the allylation and prevent hydrolysis possibly catalyzed by the indium salts in aqueous media.
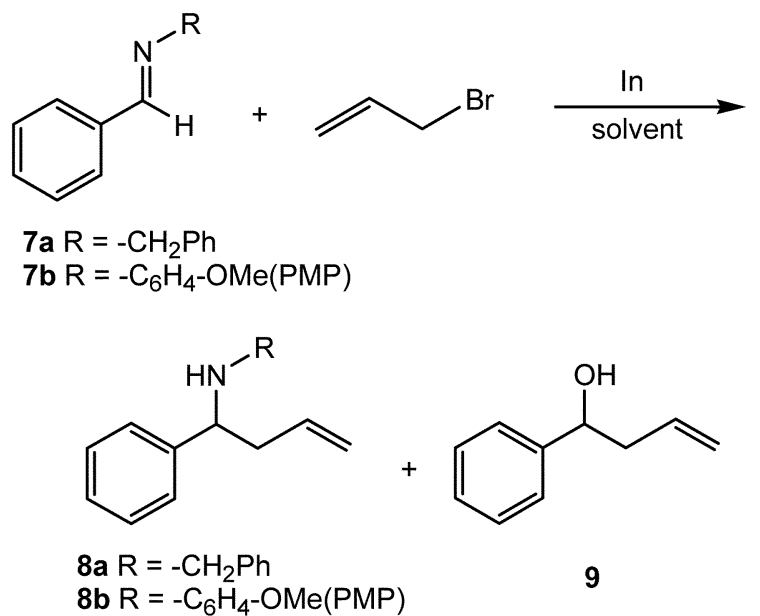

\section{Experimental Section}

All materials and solvents were purchased from either Sigma-Aldrich or Tokyo Chemical Tndustries Co. ${ }^{\mathrm{H}} \mathrm{H}$ NMR and ${ }^{13} \mathrm{C}$ NMR spectra were recorded on a Bruker DPX-300. The chemical shifts are reported in ppm on $\delta$ scale downficld from TMS, and signal patterns are indicated as follows: s, singlet; d, doublet; 1 , triplet; m, multiplet; br, broad peak.

Ethyl 2-( $N$-(4-methoxy)phenyl)amino-4-pentenoate (4a). To a mixture of ethyl 2-(4-methoxyphenylimino)acetate $(30$ $\mathrm{mg}, 0.14 \mathrm{mmol}$ ) and indium powder (20 $\mathrm{mg}, 0.17 \mathrm{mmol})$ in THF $(1.5 \mathrm{~mL})$ and saturated aqueous ammonium chloride $(1.5 \mathrm{~mL})$ was added acetic acid $(50 \mu \mathrm{L}, 0.86 \mathrm{mmol})$ at rom temperature. While stirring the mixture allyl bromide $(25$ $\mu \mathrm{L}, 0.29$ mmol) was added slowly. The mixture was stirred for $3 \mathrm{~h}$ at room temperature. The mixture was extracted with ether $(3 \times 10 \mathrm{~mL})$. The organic layer was dried $\left(\mathrm{MgSO}_{4}\right)$ and concentrated. Purification by flash chromatography (Hexane : Ethyl acetate $=5: 1$ ) provided the desired product as a transparent yellow licquid ( $32 \mathrm{mg}, 88 \%$ ).

${ }^{\prime} \mathrm{H}$ NMR (300 MHz, CDCCl $) \delta 6.77(\mathrm{~d}, 2 \mathrm{H}, J=8.8 \mathrm{~Hz}, 2 \mathrm{x}$ ArH in p-methoxyphenyl), $6.60(\mathrm{~d}, 2 \mathrm{H}, J=8.8 \mathrm{~Hz}, 2 \times \mathrm{ArH}$ in $p$-methoxyphenyl), 5.80 (dddd, $1 \mathrm{H}, J=7.2,7.2,10,17$ $\left.\mathrm{Hz}, \mathrm{CH}_{2}-\mathrm{Cl}=\mathrm{CH}_{2}\right), 5.16$ (bd, $1 \mathrm{H}, J=17 \mathrm{~Hz}$, one of $\mathrm{CH}_{2}-$ $\left.\mathrm{CH}=\mathrm{C} I_{2}\right), 5.15\left(\mathrm{bd}, 1 \mathrm{H}, J=10 \mathrm{~Hz}\right.$, one of $\left.\mathrm{CH}_{2}-\mathrm{CH}=\mathrm{C} / I_{2}\right)$, 4.18 (c) $\left.2 \mathrm{H}, J=7.1 \mathrm{~Hz},-\mathrm{OCH}_{2}-\mathrm{CH}_{3}\right), 4.05$ (t, $1 \mathrm{H}, J=6.1$ $\left.\mathrm{Hz},-\mathrm{CH}_{2}(\mathrm{NH}) \mathrm{Cl} / \mathrm{-C}=\mathrm{O}\right), 3.91$ (bs, $\left.1 \mathrm{H},-\mathrm{NH}\right), 3.74(\mathrm{~s}, 3 \mathrm{H}$, $-\mathrm{C}_{6} \mathrm{H}_{4} \mathrm{OC}\left(I_{3}\right), 2.45-2.65\left(\mathrm{~m}, 2 \mathrm{H},=\mathrm{CH}-\mathrm{C} I_{2}-\mathrm{CH}(\mathrm{NH})\right), 1.24$ $\left(\mathrm{t}, 3 \mathrm{H}, J=7.1 \mathrm{~Hz},-\mathrm{OCH}_{2} \mathrm{CH}_{3}\right) ;{ }^{13} \mathrm{C}$ NMR $\left(75 \mathrm{MHz}, \mathrm{CCCl}_{3}\right)$ $\delta 173.6,152.7,140.7,132.9,118.8,115.2,114.8,61.0,57.2$, $55.7,37.2,14.2$.

Onc-pot allylation: Typical procedure. Ethyl glyoxylate (polymeric form, $47 \%$ in toluene, $32 \mathrm{mg}, 0.15 \mathrm{mmol}$ ) and $p$ - 
anisidine $(18 \mathrm{mg}, 0.15 \mathrm{mmol})$ were dissolved in THF $(2 \mathrm{~mL})$ and stirred for $15 \mathrm{~min}$ at room temperature. To the resulting solution was added indium powder (20 $\mathrm{mg}, 0.18 \mathrm{mmol})$ and allyl bromide ( $25 \mu \mathrm{L}, 0.29 \mathrm{mmol})$. THF $(1 \mathrm{~mL})$ and saturated aqueous ammonium chloride $(3 \mathrm{~mL})$ and acetic acid $(51 \mu \mathrm{L}$, $0.88 \mathrm{mmol}$ ) were added successively to the reaction mixture. The mixture was stirred for $5 \mathrm{~h}$ at room temperature until the reaction was completed. The mixture was extracted with ether $(3 \times 10 \mathrm{~mL})$. The organic layer was dried $\left(\mathrm{MgSO}_{4}\right)$ and concentrated. Purification by flash chromatography (hexane : ethyl acetate $=5: 1$ ) provided the desired product as a transparent yellow liquid ( $31 \mathrm{mg}, 85 \%$ ).

Compound 4b: 'H NMR (300 MHz, $\left.\mathrm{CDCl}_{3}\right) \delta 6.77(\mathrm{~d}$, $2 \mathrm{H}, J=8.9 \mathrm{~Hz}, 2 \mathrm{x}$ ArH in $p$-methoxyphenyl), 6.59 (d, $2 \mathrm{H}, J$ $=8.9 \mathrm{~Hz}, 2 \times \mathrm{ArH}$ in $p$-methoxyphenyl), $4.90(\mathrm{bs}, 1 \mathrm{H}$, one of $\left.=\mathrm{CH}_{2}\right), 4.83\left(\mathrm{bs}, 1 \mathrm{H}\right.$, one of $\left.=\mathrm{CH}_{2}\right), 4.17(\mathrm{q}, 2 \mathrm{H}, J=7.1 \mathrm{~Hz}$, $\left.\mathrm{OCH}_{2} \mathrm{CH}_{3}\right), 4.08(\mathrm{t}, 2 \mathrm{H}, J=7.1 \mathrm{~Hz},-\mathrm{NHCH}-\mathrm{C}=\mathrm{O}$ ), 3.80 (bs, $1 \mathrm{H}, \mathrm{NH}), 3.73\left(\mathrm{~s}, 3 \mathrm{H},-\mathrm{OCH}_{3}\right), 2.55(\mathrm{dd}, 1 \mathrm{H}, J=6.5,13.8$ $\mathrm{Hz}$, one of $\left.=\mathrm{C}-\mathrm{CH}_{2}-\mathrm{C}(\mathrm{NH})\right), 2.47(\mathrm{dd}, 1 \mathrm{H}, J=8.0,13.8 \mathrm{~Hz}$, one of $\left.=\mathrm{C}-\mathrm{C} H_{2}-\mathrm{C}(\mathrm{NH})\right), 1.78\left(\mathrm{~s}, 3 \mathrm{H}, \mathrm{CH}_{3}-\mathrm{C}=\right), 1.23(\mathrm{t}, 3 \mathrm{H}, J$ $\left.=7.1 \mathrm{~Hz},-\mathrm{OCH}_{2} \mathrm{CH}_{3}\right) ;{ }^{13} \mathrm{C} \mathrm{NMR}\left(75 \mathrm{MHz}, \mathrm{CDCl}_{3}\right) \delta 174.1$, $152.7,140.9,140.8,115.0,114.8,114.3,61.0,56.2,55.7$, $41.4,21.9,14.2$.

Compound 4c: 'H NMR ( $\left.300 \mathrm{MHz}, \mathrm{CDCl}_{3}\right) \delta 6.75(\mathrm{~d}, 2 \mathrm{H}$, $J=8.9 \mathrm{~Hz}, 2 \times \mathrm{ArH}$ in $p$-methoxyphenyl), 6.60 (d, $2 \mathrm{H}, J=$ $8.9 \mathrm{~Hz}, 2 \times \mathrm{ArH}$ in $p$-methoxyphenyl), 5.95 (dd, $1 \mathrm{H}, J=$ $\left.10.8,17.3 \mathrm{~Hz}, \mathrm{CH}_{2}-\mathrm{CH}=\mathrm{CH}_{2}\right), 5.15(\mathrm{~d}, 1 \mathrm{H}, J=10.8 \mathrm{~Hz}$, one of $\left.\mathrm{CH}_{2}-\mathrm{CH}=\mathrm{CH}_{2}\right), 5.12\left(\mathrm{~d}, 1 \mathrm{H}, J=17.3 \mathrm{~Hz}\right.$, one of $\mathrm{CH}_{2}-$ $\left.\mathrm{CH}=\mathrm{CH}_{2}\right), 4.14\left(\mathrm{q}, 2 \mathrm{H}, J=7.1 \mathrm{~Hz},-\mathrm{OCH}_{2}-\mathrm{CH}_{3}\right), 3.8-4.0(\mathrm{~m}$, $2 \mathrm{H}, \mathrm{NH}$ and $(\mathrm{NH}) \mathrm{CH}-\mathrm{C}=\mathrm{O}), 3.73\left(\mathrm{~s}, 3 \mathrm{H},-\mathrm{C}_{6} \mathrm{H}_{4} \mathrm{OCH} H_{3}\right), 1.23$ (t, $\left.3 \mathrm{H}, J=7.1 \mathrm{~Hz},-\mathrm{OCH}_{2} \mathrm{CH} H_{3}\right), 1.20$ (s, 3H, $\left.-\mathrm{C}-\mathrm{CH} H_{3}\right), 1.14$ $\left(\mathrm{s}, 3 \mathrm{H},-\mathrm{C}-\mathrm{C} H_{3}\right) ;{ }^{13} \mathrm{C} \mathrm{NMR}\left(75 \mathrm{MHz}, \mathrm{CDCl}_{3}\right) \delta 173.1,152.7$, $143.5,141.4,115.3,114.8,114.0,66.0,60.6,55.7,40.6$, $24.9,23.7,14.3$.

Compound 4d: ${ }^{1} \mathrm{H}$ NMR $\left(300 \mathrm{MHz}, \mathrm{CDCl}_{3}\right) \delta 7.22(\mathrm{~d}$, $2 \mathrm{H}, J=8.9 \mathrm{~Hz}, 2 \times \mathrm{ArH}$ in $p$-methoxyphenyl), 6.60 (d, $2 \mathrm{H}, J$ $=8.9 \mathrm{~Hz}, 2 \times \mathrm{ArH}$ in $p$-methoxyphenyl), $6.25(\mathrm{~d}, 1 \mathrm{H}, J=1$ $\mathrm{Hz}$, one of $\left.=\mathrm{CH}_{2}\right), 5.67\left(\mathrm{~d}, 1 \mathrm{H}, J=1 \mathrm{~Hz}\right.$, one of $\left.=\mathrm{CH}_{2}\right), 4.23$ (t, $1 \mathrm{H}, J=6.8 \mathrm{~Hz}, \mathrm{NH}-\mathrm{C} H-\mathrm{C}=\mathrm{O}$ ), 4.13 (q, $2 \mathrm{H}, J=7.1 \mathrm{~Hz}$, $\left.-\mathrm{OCH}_{2}-\mathrm{CH}_{3}\right), 3.97(\mathrm{bs}, 1 \mathrm{H}, \mathrm{NH}), 3.77\left(\mathrm{~s}, 3 \mathrm{H}, \mathrm{COOCH}_{3}\right)$, $3.73\left(\mathrm{~s}, 3 \mathrm{H},-\mathrm{C}_{6} \mathrm{H}_{4} \mathrm{OCH} H_{3}\right), 2.88(\mathrm{dd}, 1 \mathrm{H}, J=6.9,13.6 \mathrm{~Hz}$, one of $\left.=\mathrm{C}-\mathrm{C} H_{z}-\mathrm{CH}(\mathrm{NH})\right), 2.70(\mathrm{dd}, 1 \mathrm{H}, J=6.8,13.6 \mathrm{~Hz}$, one of $\left.=\mathrm{C}-\mathrm{CH} H_{2}-\mathrm{CH}(\mathrm{NH})\right), 1.22\left(\mathrm{t}, 3 \mathrm{H}, J=7.1 \mathrm{~Hz}, \mathrm{OCH}_{2} \mathrm{CH}_{3}\right) ;{ }^{13} \mathrm{C}$ NMR $\left(75 \mathrm{MHz}, \mathrm{CDCl}_{3}\right) \delta 173.5,167.2,152.7,140.5,136.0$, $128.3,115.1,114.8,61.0,57.0,56.7,52.1,35.6,14.2$.

Compound 4e: 'H NMR ( $\left.300 \mathrm{MHz}, \mathrm{CDCl}_{3}\right) \delta 6.78(\mathrm{~d}, 2 \mathrm{H}$,
$J=8.9 \mathrm{~Hz}, 2 \times \mathrm{ArH}$ in $p$-methoxyphenyl), 6.62 (d, $2 \mathrm{H}, J=$ $8.9 \mathrm{~Hz}, 2 \times \mathrm{ArH}$ in $p$-methoxyphenyl), 5.33 (q, $1 \mathrm{H}, J=6.5$ $\left.\mathrm{Hz}, \mathrm{C} H=\mathrm{C}=\mathrm{CH}_{2}\right), 4.91-4.96(\mathrm{~m}, 2 \mathrm{H}), 4.54(\mathrm{~b}, 1 \mathrm{H},=\mathrm{C}-$ $\mathrm{C} H(\mathrm{NH})), 4.22\left(\mathfrak{q}, 2 \mathrm{H}, J=7.1 \mathrm{~Hz},-\mathrm{OCH}_{2}-\mathrm{CH}_{3}\right), 4.13-4.2$ (b, $1 \mathrm{H}, \mathrm{NH}), 3.74\left(\mathrm{~s}, 3 \mathrm{H}, \mathrm{C}_{6} \mathrm{H}_{4} \mathrm{OCH}_{3}\right), 1.28(\mathrm{t}, 3 \mathrm{H}, J=7.1$ $\left.\mathrm{Hz}, \mathrm{OCH}_{2} \mathrm{CH}_{3}\right) ;{ }^{13} \mathrm{C} \mathrm{NMR}\left(75 \mathrm{MHz}, \mathrm{CDCl}_{3}\right) \delta 208.3,171.8$, $152.7,140.0,115.3,114.8,89.3,78.8,61.5,56.4,55.6,14.2$.

Acknowledgements. This work was supported by the Regional Research Centers Program of the Ministry of Education \& Human Resources Development in Korea.

\section{References}

I. (a) Kang, H.-Y,; Kim, Y.-T.; Yu, Y.-K.; Cha, J. H.; Cho, Y. S.; Koh, H. Y. Syntet 2004, 45. (b) Cha, J. H.; Cho, Y. S.; Koh, H. Y.; Lee, E.; Kim, Y.-T.; Yang, H.-H.; Kang, H.-Y. Bull. Korean Chen. Soc. 2004, 25, 1123. (c) Kang. H.-Y.; Yu, Y.-K. Bull. Korean Chen. Soc. 2004, 25, 1627. (d) Nouyen, V. C.; Kim, Y.-T.; Yu. Y.K.; Kang, H.-Y, Bull. Korean Chem. Soc. 2005, 26, 7I1, (e) Lee, J. H.; Park, Y. S.; Nam, M. H.; Lee, S. H.; Cho, M. Y.; Yoon, C. M. Bull. Korean Chem. Soc. 2005, 26, 496.

2. Lalyanam, N.; Rao, G. V. Tetrahedron Letf. 1993, 34, 1647.

3. (a) Beuchet, P.; Le Marrec, N.; Mosset, P. Tetrahedron Lett. 1992, 33, 5959. (b) Cjoudhury, P. K.; Foubelo, F.; Yus, M. J. Org. Chen. 1999, 64, 3376. (c) Choucair, B.; Léon, H.; Miré, M.-A.; Lebreton, C.; Mosset, P. Org. Lett. 2000, 2, 1851.

4. (a) Jin, S.-J.; Araki, S.; Butsugan, Y. Bull. Chem. Soc. Jpn. 1993, 66, 1528. (b) Loh, T.-P.; Ho, D. S.-C.; Xu, K.-C.; Sim, K.-Y. Tetrahedron Lett. 1997, 38, 865. (c) Lee, J. G; Choi, K. J.; Pae, A. N.; Koh, H. Y.; Kang, Y.; Cho, Y. S. J. Chent. Soc. Perkin Trants. I $2002,1314$.

5. Vilaivan, T.; Winotapan, C.; Shinada, T.; Ohfune, Y, Tetrahedron Lett, 2001, 42,9073.

6. Vilaivan, T.; Winotapan, C.; Banphavichit, V.; Shinada, T.; Ohfune, Y. J. Org. Chem. 2005, 70, 3464.

7. (a) Chan. T. H.; Lu. W. Tetrahedron Lett. 1998, 39, 8605-8608. (b) Lu, W; Chan, T. H. J. Org. Chem, 2000, 65, 8589. (c) Lu, W; Chan, T. H. ibid, 2001, 66, 3437.

8. Kumur, H. M. S.; Anjaneyulu, \$.; Reddy, E. J.; Yadav, J. \$. Tetrahedron Letf. $2000,41,9311$.

9. Prajapati, D.; Laskar, D. D.; Gogoi, B. J.; Devi, G. Tetrahedron Lett. 2003, 44, 6755 .

10. Hannesian, S.; Yang R.-Y. Tetrahedron Lett. 1996, 37, 5273.

11. Miyabe, H.; Nishimura, A.; Ueda, M.; Nailo, T. Chem. Commun. 2002,1454 .

12. (a) Ritson, D. J.; Cox, R. J.; Berge, J. Org. Bionol. Chem. 2004, 2, 1921. (b) Bernardi, L.; Cere, V.; Fermoni, C.; Pollicino, S.; Ricei, A. J. Org. Chem. 2003, 68, 3348 .

13. (a) Miyabe, H.; Yamaoka, Y.; Nailo, T.; Takemolo, Y, J. Org. Chem. 2003, 68, 6475. (b) Miyabe, H.; Yamaoka, Y,; Naito, T.; Takemolo, Y. J. Org. Chem. 2004, 69, 1415. 